\title{
Physical distribution challenges and adaptations: A qualitative study of South Africa-based organisations operating in emerging African markets
}

\begin{tabular}{|c|c|}
\hline \multicolumn{2}{|c|}{$\begin{array}{l}\text { Authors: } \\
\text { Stela D.J. Jaqueta }{ }^{1} \\
\text { Emma N. Mashilo }^{1} \text { (D) } \\
\text { Kelvinne Mocke }^{1} \text { (D) } \\
\text { Assilah F.A. Agigi }^{1}\end{array}$} \\
\hline \multicolumn{2}{|c|}{$\begin{array}{l}\text { Affiliations: } \\
\text { 1Department of Business } \\
\text { Management, Faculty of } \\
\text { Economic and Management } \\
\text { Sciences, University of } \\
\text { Pretoria, Pretoria, } \\
\text { South Africa }\end{array}$} \\
\hline \multicolumn{2}{|c|}{$\begin{array}{l}\text { Corresponding author: } \\
\text { Kelvinne Mocke, } \\
\text { kelvinne.mocke@up.ac.za }\end{array}$} \\
\hline \multicolumn{2}{|c|}{$\begin{array}{l}\text { Dates: } \\
\text { Received: } 08 \text { Oct. } 2019 \\
\text { Accepted: } 03 \text { Feb. } 2020 \\
\text { Published: } 18 \text { Mar. } 2020\end{array}$} \\
\hline \multicolumn{2}{|c|}{$\begin{array}{l}\text { How to cite this article: } \\
\text { Jaqueta, S.D.J., Mashilo, E.N., } \\
\text { Mocke, K. \& Agigi, A.F.A., } \\
\text { 2020, 'Physical distribution } \\
\text { challenges and adaptations: } \\
\text { A qualitative study of } \\
\text { South Africa-based } \\
\text { organisations operating in } \\
\text { emerging African markets', } \\
\text { Journal of Transport and } \\
\text { Supply Chain Management } \\
\text { 14(0), a475. https://doi. } \\
\text { org/10.4102/jtscm.v14i0.475 }\end{array}$} \\
\hline \multicolumn{2}{|c|}{$\begin{array}{l}\text { Copyright: } \\
\text { (C) 2020. The Authors. } \\
\text { Licensee: AOSIS. This work } \\
\text { is licensed under the } \\
\text { Creative Commons } \\
\text { Attribution License. }\end{array}$} \\
\hline \multicolumn{2}{|l|}{ Read online: } \\
\hline 口its: & $\begin{array}{l}\text { Scan this QR } \\
\text { code with your } \\
\text { smart phone or } \\
\text { mobile device } \\
\text { to read online. }\end{array}$ \\
\hline
\end{tabular}

Background: There has been substantial research addressing physical distribution challenges within emerging markets, such as Asia and South America. However, this topic is not sufficiently covered for emerging markets in Africa. Emerging markets in Africa present unique challenges that should be known to any manager intending on operating in these markets.

Objectives: This study aims to provide insights into the prevalent physical distribution challenges that organisations face in emerging markets in Africa. Emphasis is placed on the adaptations organisations make to overcome these challenges. The study focused on multinational organisations operating in the fast-moving consumer goods, third-party logistics and retail industry, mostly from the perspective of the South African division.

Method: A generic qualitative research design was employed. Twelve semi-structured interviews were conducted with middle to senior managers who have knowledge of their organisation's distribution operations in African markets.

Results: The findings highlight the existence of prevalent challenges identified in the literature, namely, border congestion, informal markets and weak infrastructure, while providing insight into the sources of these challenges. Furthermore, other challenges, such as warehouse system misalignment, order processing times and variable border legislation are highlighted. Adaptations to these areas are discussed.

Conclusion: The study provides further academic understanding of the challenges multinationals are facing and adaptations they are implementing when trading in emerging African markets. Theoretically, the body of knowledge of physical distribution is enhanced by addressing distribution challenges in the African context. Additionally, the study assists organisations to understand how they can possibly adapt their physical distribution operations.

Keywords: physical distribution; emerging markets; challenges; adaptations; Africa.

\section{Introduction}

'Whoever can manage supply chains in Africa wins', says Richard Brasher, CEO of Pick n Pay, one of South Africa's most prominent retailers. Expansion into African markets, apart from South Africa, has been somewhat of a hit and miss for many firms. In the Nigerian market, Shoprite, another South African retailer, has seen significant growth, mainly through substantial investments in infrastructure. Most emerging markets are characterised by weak infrastructure, insufficient custom procedures and the dominance of informal markets (Dadzie, Winston \& Hinson 2015; Hirschinger et al. 2015; Shacklett 2014). Therefore, success in these emerging markets requires organisations to develop distribution strategies that are compatible with the contextual challenges in these markets (Craighead et al. 2017; Dadzie et al. 2015; Hirschinger et al. 2015). Emerging markets often require organisations to restructure their product and distribution strategies (Fawcett \& Waller 2015; RiveraSantos et al. 2015). An understanding of the existing distribution challenges in Africa is essential in being able to develop the appropriate distribution strategies to succeed (Fawcett \& Waller 2015:235; Parmigiani \& Rivera-Santos 2014:62-63; Prahalad 2012:10). Therefore, investigating the distribution challenges within these markets can shed some light on the required contextual distribution practices and appropriate strategies (Amoako-Gyampah \& Boye 2001:61).

Physical distribution consists of activities that facilitate the movement of finished products and raw materials from the point of origin to final consumption in a way that adds value to customers 
at the lowest possible cost (Christopher 2016:3; Ravet 2013:25). It includes several activities such as transportation, warehousing, packaging, material handling, information systems, inventory management and order processing to facilitate the movement of products (Carter, Rogers \& Choi 2015:91; Croxton 2003:29; Larson, Poist \& Halldórsson 2007:2). Transportation, warehousing and order processing represent the main activities in the distribution function (Christopher 2016:2; Croxton 2003:29; Larson et al. 2007:2).

The physical infrastructure in most African markets is underdeveloped (Agyenim-Boateng \& Russo 2015:2; Craighead et al. 2017:2; Eifert, Gelb \& Ramachandran 2008:1542), which makes transportation costly and challenging (Berman \& Blade 2013:8; Castell 2016:32). Border post-congestion is a challenge because of repeated physical inspection of products, inefficiency, paper-based documentation processes, strikes and delays in permits that delay incoming products (Dadzie 1990:3; World Bank 2016:39). In addition to adapting to the infrastructure and border delays, organisations often have to find cost-effective ways of serving the informal market. A significant proportion of the retail market in emerging markets in Africa is facilitated through informal structures such as street hawkers and vendors across urban and rural areas (Dadzie 1990:31; Rivera-Santos et al. 2015:65; Shacklett 2014:31). Although studies on the bottom of the economic pyramid (BOP) address issues in terms of serving these informal markets, minimal studies have investigated the specific distribution issues that companies face in this regard (Iyer, Lee \& Roth 2013:56; Steven \& Britto 2016:235; Wu et al. 2006:501).

This generic qualitative study aimed to explore the physical distribution challenges organisations face in emerging African markets. Additionally, this study aimed to explore and stimulate the need for future research highlighting the physical distribution challenges that organisations need to be aware of when distributing into African markets. These markets present a unique case in that the culture, society and politics within member countries on the continent are multifaceted and complex (Jackson 2011:532). Each country has its nuances and presents a unique set of challenges (Vögel 2014).

The following research questions guided the study:

- What are the most prevalent physical distribution challenges organisations face within emerging African markets?

- How do organisations adapt their physical distribution activities in response to challenges in emerging African markets?

The study provides the following contributions: firstly, it provides insights into the specific distribution challenges of transportation, warehousing and order processing in emerging markets in Africa, which have not been sufficiently addressed in previous research (Amoako-Gyampah \& Boye
2001:45; Darkow, Weidmann \& Lorentz 2015:61). Secondly, it sheds light on some of the considerations that organisations will have to bear in mind when structuring their distribution activities within these markets (Darkow et al. 2015:27; Iyer et al. 2013:235; Prahalad 2012:10; Rivera-Santos et al. 2015:64). Ultimately, this study can serve as an initial guideline to those organisations planning to expand into these markets.

The remainder of the article is structured as follows: a literature review is presented, introducing the broad focus of research in physical distribution, describing the physical distribution activities, physical distribution in emerging markets and physical distribution in African markets. Then, the methodology of the study is given, followed by a discussion of the findings of the study. Finally, conclusions are drawn, together with managerial implications and future research recommendations.

\section{Literature review Physical distribution}

Physical distribution is concerned with the movement of finished and raw material products from the point of origin to the point of consumption (Bowersox 1969:66; Rogers \& Leuschner 2004:62-63; Schary 1970:6; Wilson 1961:22). It covers a broad range of activities for the efficient movement of products or services (Khan et al. 2009:42). Physical distribution found its origin in the military in the 1950s, where the focus was on providing the right materials at the right time (Hauk 1964:12; Southern 2011:55). Physical distribution creates place, form, quantity and possession utility of products along the supply chain (Khan et al. 2009:42). Lu and Yang (2010:282) and Rexhausen, Pibernik and Kaiser (2012:270) discuss that distribution performance quality, in terms of transportation and warehousing, is one of the key elements for supply chain excellence. This is one of the reasons why organisations are investing in their physical distribution activities (Esper, Fugate \& Davis-Sramek 2007:57). Rexhausen et al. (2012:278) recommend that supply chain managers should start viewing physical distribution management as an essential function for effective operations and one that leads to competitive advantage.

As discussed previously, physical distribution covers many activities in the supply chain. For this study, three main areas of physical distribution are explored: order processing, transportation and warehousing. The justification for the focus on these areas is threefold: firstly, these activities have a direct influence on meeting consumer needs. Secondly, these activities influence the level of commitment the organisation has in a particular market (Hu 2018:610). Thirdly, these activities are usually cited as obstacles for management in emerging markets, which is often attributed to 'weak infrastructure' (Chikweche \& Fletcher 2012:513).

\section{Order processing}

Order processing is described as the communication message that sets the physical distribution process in motion 
(Croxton 2003:26). It involves activities such as planning, execution, communication and specifications regarding the delivery of products to customers (Zhang, Lee \& Xu 2010:213). Order processing is connected with information system technologies to allow for a seamless flow of operations (Schlesinger et al. 2001:15). The order processing function connects the warehouse to allow visibility of stock and transportation for the scheduling of delivery. However, to allow for the seamless flow of information, the information systems should be compatible between multiple channel members' systems (Espino-Rodríguez \& Rodríguez-Díaz 2014:12; Lau \& Lee 2000:599). Information systems in physical distribution are used to enhance the flexibility and responsiveness of the organisation's activities and are often the glue that links the activities (Lau \& Lee 2000:600).

\section{Transportation}

Transportation provides the physical movement of products from one location to another, typically the source to its destination, and it becomes significant when it expands over countries and continents (Villarreal, Garcia \& Rosas 2009:72). According to the logistics barometer, transportation is the highest cost of physical distribution, accounting for roughly $57 \%$ (as a percentage of gross domestic product [GDP]) of logistics costs in South Africa (Havenga et al. 2016:9). Transportation involves activities such as route planning, cargo tracking and shipment notices (Zhang et al. 2010:49). Leveraging transportation routes, schedules and bundling orders to achieve economies of scale improves the organisation's physical distribution through reduced travel distances and efficient load capacity (Lu \& Yang 2010:281; Rexhausen et al. 2012:272).

\section{Warehousing}

A warehouse's primary function is to store raw materials and finished products (Gu, Goetschalckx \& McGinnis 2010:540). The main activities performed in the warehouse include receiving, storage, order picking, accumulation, sorting and shipping (Gu et al. 2010:540; Rexhausen et al. 2012:272; Van den Berg \& Zijm 1999:520). The location of the warehouse impacts the organisation's responsiveness and lead time to customers (Esper et al. 2007:58; Mueller \& Mueller 2007:55; Shang et al. 2009:147). Inappropriate warehousing locations can lead to delivery delays, inefficient distribution and increased logistics cost (Chan, Kumar \& Choy 2007:726). An efficient warehouse improves the organisation's service levels, which leads to reduced delivery times and increased customer satisfaction (Shang et al. 2009:160). The warehouse should be designed in such a way that it provides continuous flow from order processing to the time products are packed for shipping.

\section{Physical distribution in emerging markets}

Institutional voids increase the difficulty of conducting businesses in emerging markets (Dadzie et al. 2015:138; Hirschinger et al. 2015:74; Shacklett 2014:30). Most notably, infrastructure problems are rife within these markets
(Craighead et al. 2017:1; Dadzie et al. 2015:138; Hirschinger et al. 2015:85; Iyer et al. 2013:233; Shacklett 2014:30). Because of lack of adequate roads, general warehousing facilities and high traffic congestion, researchers have noted that many multinationals fall short when attempting to capture a share of the market as distribution costs rise beyond a profitable point (Craighead et al. 2017:1; Flynn, Huang \& Zhao 2015:3). Successful operations may require an investment in the infrastructure to support operations (Flynn et al. 2015:3; Hirschinger et al. 2015:85).

Furthermore, insufficient border procedures act as a logistical barrier that contributes to the challenge of conducting business in emerging markets (Dadzie 1990:3; Hirschinger et al. 2015:74). Repeated physical inspection of products, strikes and permit delays make it challenging for organisations to transport products over the borders (Dadzie 1990:3; World Bank 2016:39). Nevertheless, entry into emerging markets is encouraged, as governments are eager to attract foreign organisations and customers (Flynn et al. 2015:1). However, the legislation does not provide an environment that is conducive for investment attraction as these borders discourage cross-border trade (Pedersen 2003:287).

Furthermore, informal markets dominate most emerging markets (Dadzie 1990:31; Parmigiani \& Rivera-Santos 2014:65). Retail activity is facilitated through informal market structures such as street hawkers and vendors in urban and rural areas (Dadzie 1990:31; Parmigiani et al. 2014:65; Shacklett 2014:31). This poses a challenge for multinational organisations that are accustomed to conducting their business through formal structures. In some cases, to facilitate trade through formal market structures, it may require an investment in infrastructure, or necessitate a change in distribution processes such as smaller order quantities and smaller delivery vehicles (Meacham , Tumms, Moolman \& de Montgolfier 2012:1; Shacklett 2014:31). Shoprite invested in the development of privately owned shopping malls in Nigeria because of the lack of infrastructure to support formal trade (Vögel 2014). Understanding the challenges in these markets should serve as a starting point for organisations to develop the appropriate strategies for effective distribution (Craighead et al. 2017:5; Flynn et al. 2015:4; Hirschinger et al. 2015:74; Shacklett 2014:29).

\section{Physical distribution in Africa}

A significant percentage of the African population resides in rural areas. Subsequently, a larger proportion of the market activity happens through street hawkers, vendors, and mom and pop shops (Dadzie 1990:31; Rivera-Santos et al. 2015:65; Shacklett 2014:31). Approximately $80 \%$ - 90\% of the retail market is informal (Hugo 2016:2; Meacham et al. 2012:4). This is a big adjustment for a multinational organisation, which predominately operates through formal structures. Companies such as Unilever, Coca-Cola and third-party logistics (3PL) providers like DHL have had to establish unique ways of distributing their products (Fawcett \& Waller 2015:234; 
Wood 2016:4). For example, DHL has an unusual distribution model in which they collaborate with laundromats and travel agencies to distribute products (Hugo 2016:13). Distributing products in the informal market through a seller with a backpack or bicycle is a norm in Nigeria (Vögel 2014). To operate successfully, an organisation needs to understand the differences in market nuances, unlike a market such as India or China, where organisations could access a sizeable market with the same market dynamics, mostly because of higher population levels (Vögel 2014). Despite the commonalities that exist in these markets, it is essential to understand the degree of their differences (Flynn et al. 2015:4).

The main argument highlighted in the literature for success in emerging markets, especially in sub-Saharan Africa, is adaptations organisations need to make to their distribution strategies to meet the challenges in these markets (Craighead et al. 2017:2; Dadzie et al. 2015:137; Hirschinger et al. 2015:73). However, how companies adjust to these challenges has brought little attention from a theoretical perspective, with most of the strategies scattered in popular articles. Foresight into these challenges could aid organisations in understanding the market dynamics (Craighead et al. 2017:5; Flynn et al. 2015:4). However, little is known about supply chain practices in Africa (Amoako-Gyampah \& Boye 2001:60; Darkow et al. 2015:28; Iyer et al. 2013:234; Mesquita, Lazzarini \& Cronin 2007:518). Furthermore, little is known about transportation, warehousing and order processing challenges in Africa (Iyer et al. 2013:56; Steven \& Britto 2016:235; Wu et al. 2006:501). The absence of this information makes it challenging for multinational organisations as they are not aware of the existing challenges and thus lack an understanding of how to successfully adapt their distribution activities (Nnamdi \& Owusu 2014:235)

The Global Powers of Retailing (GPR) report by Deloitte (2017) annually reports the top 250 retailers in the world and provides insights into the performance of these companies across different product categories, geographies and sectors. For the financial year 2015, this report revealed some interesting statistics. The Africa and Middle East regions showed a $5.8 \%$ growth in net profits and a $19.1 \%$ growth in retail revenue - both figures are substantially above the average growth and revenue rates in other regions of the world. China is a close second, with a retail revenue growth at $12.9 \%$. Interestingly, the GPR report also indicates a mere $13.6 \%$ and $13.8 \%$ of retail revenue coming from foreign operations for the North American and united states regions, respectively. In addition, the United Nations Economic Commission for Africa indicated that $90 \%$ of all transactions within the African retailing sector still occur through informal channels. Admittedly, there is a great opportunity for growth within emerging markets, especially the African or Middle East regions (Ciuci 2011:1; Lee 2006:303; Luiz 2006:625; Lysonski \& Durvasula 2013:493; Ouma 2012:836). 'There is a sense that all businesses have to do is invest and set up shop, and they will rake in the millions and walk away. In Africa, it is not that simple', a statement by George de Beer, Financial Director of Imperial Logistics Africa. Imperial is a listed diversified industrial service and retail conglomerate, with a strong focus in the 3PL industry. Imperial has been one of the most prominent logistics players in Africa, with operations in 14 African countries. George de Beer adds that based on the experience of Imperial, the movement of goods within African markets is highly sensitive to various institutional factors, such as political changes, erratic legislation changes and poorly developed infrastructure (Dadzie et al. 2015:137; Games 2012:142). The understanding that specific institutional factors can have an impact on a supply chain operating in an emerging market is supported by several researchers including Huq, Chowdhury and Klassen (2016:19), Shou, Zheng and Zhu (2016:38), Steven and Britto (2016:55), Wang, Li and Chang (2016:69) and Zhou et al. (2016:1). As a result, these factors should be considered when planning for distribution in African markets.

\section{Methodology Research design}

The study adopted a generic qualitative research design. A generic qualitative research design explores the participant's subjective opinions, experiences and beliefs of circumstances around them (Percy, Kostere \& Kostere 2015:78). The study gathered opinions and perceptions of managers of multinational organisations, operating in different emerging African markets, to understand the physical distribution challenges and the adaptations implemented to address the existing challenges. Most of these managers worked for the South African branch of the multinational from where expansion further into Africa takes place. Moreover, managers of these multinational organisations perceive problems differently, and thus, exploring their subjective understanding of the problems in these markets might yield different results. The purpose of a generic qualitative research design is to provide a detailed depiction of the participants' experiences and opinions for a specific phenomenon (Lambert \& Lambert 2012:255; Neergaard et al. 2009:2). Emerging markets in Africa are vastly different, with each market presenting its own set of challenges; thus, management account of challenges varies across markets (Vögel 2014).

\section{Sampling}

The units of analysis for this study were multinational organisations with a physical presence in emerging African markets. The units of observation were managers working within these organisations. A total of 12 semi-structured interviews were conducted, with at least one participant per organisation.

In selecting the organisations to participate in the study, a homogeneous sampling, a form of purposive sampling, was used to select organisations with similar characteristics (Creswell 2012:518; Polit \& Beck 2012:519). The participating organisations were all multinationals operating in more than one emerging African market outside of South Africa, with a physical presence in those markets in the form of a sales office, store or a distribution facility. The specific sampling 
TABLE 1: Profile of the study participants.

\begin{tabular}{|c|c|c|c|c|}
\hline Pseudonym & Position & Gender & Firm & Length of the interview (in minutes) \\
\hline P001 & DC manager & Male & C001 & 73 \\
\hline P002 & Depot manager & Male & CO02 & 25 \\
\hline P003 & Key accounts manager & Male & $\mathrm{COO3}$ & 54 \\
\hline P004 & Head of business development and account manager for Africa & Male & C003 & 32 \\
\hline P005 & Supply chain IT & Female & COO4 & 37 \\
\hline P006 & Export specialist & Female & CO05 & 47 \\
\hline P008 & Senior brand manager & Female & C006 & 40 \\
\hline P009 & Senior supervisor & Male & $\mathrm{C} 007$ & 20 \\
\hline P010 & Import and export manager & Male & $\mathrm{C} 008$ & 31 \\
\hline P011 & Operations executive & Male & $\mathrm{C} 009$ & 47 \\
\hline P012 & General manager & Male & $\mathrm{C} 010$ & 23 \\
\hline Average & - & - & - & 38 \\
\hline
\end{tabular}

DC, distribution center; IT, Information technology.

method was selected because the objective of the study was to understand the physical distribution challenges that multinational organisations are facing in the African markets, and thus having a physical presence in those markets is a prerequisite for the identification of these challenges (Polit \& Beck 2012:519). The organisations had footprints in most Southern African countries, including Nigeria, Ghana and Kenya. The participating organisations operated in the fast-moving consumer goods (FMCGs) industry that manufactured and distributed products such as toiletries, cosmetics, processed foods and beverages. Third-party logistics providers that provide logistics service in warehousing, transportation and order processing and the retail industry, mainly selling grocery items and fashion apparel, were also part of the sample.

Homogeneous sampling was also chosen in selecting the individual participants for the study. The characteristics that participants had to share included the following: (1) the participant had to hold a position of middle or top management and (2) the participant must have or previously had the responsibility of managing distribution in those markets. Table 1 provides the profiles of individual participants.

\section{Data collection}

The data for the study were gathered through three semistructured Skype interviews, five telephonic semistructured interviews and four face-to-face semi-structured interviews. Skype and telephone interviews were used because of geographical dispersion. In exploring physical distribution challenges in emerging markets in Africa, semistructured interviews were the most appropriate because the flexible and adaptable structure facilitated the collection of in-depth information without predetermining the results (Rowley 2012:391-394; Saunders, Lewis \& Thornhill 2016:301).

A discussion guide was developed from the review of the study's research questions and the literature. Two academics one qualitative methodologist and an experienced academic in the discipline of supply chain management - critically evaluated the first draft of the discussion guide. A pilot study was conducted with one participant who closely mirrored the target population of the study as outlined in the sampling requirements to determine the appropriateness of the questions in addressing the research questions. The pilot study was able to retrieve the information required to address the study's research questions. Thus, no significant changes were made to the discussion guide.

Data for the study were gathered during August and September 2018. The 12 semi-structured interviews lasted from 23 to $78 \mathrm{~min}$, with an average of $38 \mathrm{~min}$. Interviews that lasted for less than 30 min were followed up with email conversations to clarify any information that was not covered in the interview. The face-to-face interviews were conducted at the participant's offices or boardroom at their place of work. All the participants granted permission for the interviews to be recorded. The researchers started each interview with a brief description of the main purpose of the study. For the face-to-face interviews, participants were asked to read and sign an informed consent form. For the Skype and telephonic interviews, participants were sent an electronic informed consent form to be read and signed and sent via email. Thereafter, the main questions contained in the discussion guide were asked, along with probing questions, to elicit detailed responses. Guest, Bunce and Johnson (2006:59) state that as few as six interviews could yield sufficient data to reach saturation or a case where no new information is gathered on a specific topic. It is important to note that given the lack of broad data collection in qualitative research, the aim of the findings is not to generalise to a broader population as with quantitative research. The aim instead with a qualitative research design is to 'shed empirical light on some theoretical concepts or principles', that is, physical distribution challenges in African markets (Yin 2017:73).

Ten interviews were transcribed by the researchers within 48 $\mathrm{h}$ of the interview. An external transcriber transcribed the remaining two interviews because of time constraints. To ensure the accuracy of the transcripts, the researchers listened to the recordings while reading the transcripts and made minor changes to ensure that the transcripts mirrored the actual recordings. 


\section{Data analysis}

The data were analysed thematically, which involved identifying, reporting and organising themes across a data set. This method of data analysis identifies the major response patterns amongst the participants who address the topic and research questions explored (Braun, Clarke \& Terry 2014:57). Following the guidelines of Braun et al. (2014:57-71) and Creswell (2012:236-253), a preliminary exploratory analysis was firstly conducted by analysing the audio recording against the transcripts. Upon the exploratory analyses of the data, inductive codes were generated based on the resulting data and supplemented with a priori codes determined beforehand to formulate a list of codes. The codes were used to code similar segments of data in the transcripts. The researchers completed these steps independently. Each researcher reviewed the other researcher's findings and perspectives to formulate a standard set of codes and themes most applicable in addressing the study's research questions, and thus, irrelevant or redundant codes were deleted. This method of analysis increased the study's trustworthiness by avoiding the biased view of one researcher. Table 1-A1 lists the codes, themes and sub-themes identified in this study. Each code is supported by a quotation extracted from the transcripts.

\section{Trustworthiness}

Lincoln and Guba (1986:73-84) identified four criteria of trustworthiness - credibility, dependability, transferability and confirmability - which were used as measures to ensure the quality and rigour of qualitative research. The study attempted to achieve credibility by using site triangulation, which involved the use of various participants from the 10 organisations to ensure that identified themes are not only applicable to one organisation (Lietz \& Zayas 2010:191). For the FMCG industry, eight participants were interviewed; for the 3PL industry, three participants were interviewed; and for fashion apparel, one participant was interviewed. This allowed for findings to be varied against each other, and conclusions could be reached based on a range of data (Shenton 2004:66). Dependability was addressed through the provision of a detailed description of the study's research design, data collection and data analysis methods (Shenton 2004:71). To satisfy the transferability criterion, detailed descriptions of the participants' position, length and number of the interview and period of data collection were documented (Shenton 2004:70).

Furthermore, the findings of a study should reflect the ideas, experiences and perspectives of participants and not those of the researcher (Shenton 2004:72). Confirmability was ensured by employing triangulation to establish a clear link between the collected data and the reviewed literature. To enhance the confirmability of this study, probes were also used during the interviews to elicit in-depth discussions in order to gather rich data and a clear understanding of the participants' experience and perspective.

\section{Ethical considerations}

The study was given ethical clearance by the University of Pretoria's Research Ethics Committee (Reference no. 15091393_14169526/20). All participants were required to read and sign a consent form. The consent form explained the purpose of the study and expressed the rights of the participant. Participation in the study was voluntary, and participants had the right to withdraw at any point in time. The consent form also assured anonymity and confidentiality. This was achieved by replacing the name of the participants and organisation with pseudonyms in the final presentation of the study.

\section{Findings}

Based on the responses of the participants, this study identified two main themes. These themes relate to the following: the physical distribution challenges faced by the participating organisations and the adaptations the organisations had to make to cope with the challenges. The themes and their related sub-themes are discussed in this section, together with the participants' quotations and linkages with the relevant literature (see Figure 1).

\section{Transportation challenges}

Transportation in emerging markets is characterised by poor road conditions, challenging terrain and unsuitable vehicles (Castell 2016:32; Mérel, Sexton \& Suzuki 2009:462). The most prevalent transportation challenges identified by participants include weak infrastructure, vehicle theft and cost fluctuation. Additionally, participants identified long lead times as a transportation challenge.

Problematic road conditions were pointed out as being the major infrastructure challenge in emerging African markets.

\begin{tabular}{|c|c|}
\hline Theme 1: Challenges & Theme 2: Adjustments \\
\hline $\begin{array}{l}\text { Transportation } \\
\text { - Weak infrastructure } \\
\text { - Long lead times } \\
\text { - Traffic congestion } \\
\text { - In-transit damages } \\
\text { - Security } \\
\text { - Cost } \\
\text { Warehousing } \\
\text { - Misaligned stock systems } \\
\text { - Manual system } \\
\text { Order processing } \\
\text { - Manual systems } \\
\text { - Lack of system support } \\
\text { Border congestion } \\
\text { - Unpredictability } \\
\text { - Constant regulation changes } \\
\text { Informal market } \\
\text { - Uneconomical quantities } \\
\text { - High costs }\end{array}$ & $\begin{array}{l}\text { Transportation } \\
\text { - Outsourcing (3PL) } \\
\text { - Safety stock } \\
\text { - Smaller vehicles } \\
\text { - Protective packaging } \\
\text { Warehousing } \\
\text { - WMS } \\
\text { - Distributor's warehouse } \\
\text { - Cross docking } \\
\text { Order processing } \\
\text { - Centralisation } \\
\text { Border congestion } \\
\text { - Pre-planning } \\
\text { - Safety stock } \\
\text { - Local representation } \\
\text { - Re-routing } \\
\text { Informal market } \\
\text { - Small vehicles } \\
\text { - Minimum order quantities } \\
\text { - Collaborative distribution }\end{array}$ \\
\hline
\end{tabular}

FIGURE 1: Summary of themes. 
Defective and unstable road pavements cause damages to fleets. Additionally, the unstable roads lead to product damage because of the significant movements within the trucks. Participants also mentioned challenges such as vehicle security and transportation cost fluctuation. Two participants reported incidents of vehicle theft and in-transit product theft, highlighting security concerns. Additionally, the cost of transportation, especially when using a 3PL, may vary on a daily or weekly basis because of exchange rate fluctuations. Together, these factors complicate the transportation planning of these firms. The following quotes represent the perceptions of the participants:

'So when you are out there, it's sort of different from an infrastructure perspective, it damages quickly in terms of wear and tear of your vehicles because of your road conditions.' (P004, male, head of business development and account manager for Africa)

'The big thing is theft. It's a common problem we had in Nigeria and Ghana. Vehicles gone missing, fuel stolen.' (P004, male, Head of Business Development and Account Manager for Africa)

'And road transport costs vary considerably, especially with the exchange rate consistently changing. As an example, the Mozambican exchange rate fluctuates daily, so those transport costs are changed daily ...' (P008, female, Senior Brand Manager)

Participants also reported lead time incidents that have an impact on the transportation of products. The lengthy geographical distances from the border to the market or from the warehouse to the different customer stores increase the lead time. The long lead times are further exacerbated by border delays, which make it difficult for participants to accurately plan transport schedules to the markets. One participant stated that the delays make products more vulnerable to damage because of the high temperatures in these countries. Furthermore, four participants stated that because of the severity of traffic congestion in some of these African markets, it could take days to move products within the markets because of the heavy city traffic. The following quotes illustrate these views:

'If you are in the middle of Nairobi, it can take a truck at least two to three hours to get out within a kilometre distance from the warehouse ... There is congestion in these countries that are sometimes, quite incredible, compared to what we experience here [South Africa].' (P004, male, Head of Business Development and Account Manager for Africa)

'... Then for us becomes an issue with the actual product on the truck because of the heat, so especially with our candy and those sort of categories, you can get products that can melt ...' (P008, female, Senior Brand Manager)

The challenges identified above are consistent with the challenges identified in the previous studies on physical distribution (Castell 2016:32; Fawcett \& Waller 2015:234). These challenges are more intensely described and more pronounced in these markets than in other markets.

\section{Transportation adaptations}

Nine participants stated that they use the aid of a 3PL partner to move products within the markets because of the high costs of using their own trucks, cross-border security concerns and the lack of in-depth market knowledge. The 3PLs have in-depth market knowledge and know-how to navigate the challenges in these markets. However, employing a distributor may present its own set of challenges. Two participants reported concerns over service levels with their distributors. In one case, the participant made an advance payment for the service as requested by the distributor; however, the distributor fled without providing the service. The participant had to resort to an alternative service provider.

Participants also stated that they apply additional protective packaging to avoid product movement and damage while in transit. To counter delays, four participants used route planning systems in order to determine alternative routes, and some used alternative borders to avoid congestion in some of the main borders. Furthermore, participants have to keep large quantities of safety stock to counter transportation delays. The solutions are presented in the following quotations:

'Where you are going to regions or areas that are not common for your business would typically then engage certain subcontractors who frequent those typical regions.' (P004, male, Head of Business Development and Account Manager for Africa)

'We will put a thicker layer of shrink wrap purely because of the poor roads that these trucks have to travel on ...' (P002, male, Depot Manager)

'So what can also happen is you can look at rerouting via different borders so going through ... you know for Zambia we experimented a little bit to try different routes to, say, instead of going through Kazungula lets go to Livingstone.' (P006, female, Export Specialist)

The findings contradict to an extent previous studies that stated that multinational organisations have to uniquely adjust their distribution activities in order to successfully trade and distribute in emerging African markets (Fawcett \& Waller 2015:234; Wood 2016:4). The participants provide generic adaptations to transport challenges they face. However, these adaptations require more significant investments of time and resources to ensure the successful delivery of products. The findings have some implications for transportation performance; firstly, companies are managing to sell to these markets but seemingly at a loss of efficiency. More time is spent on planning activities, more resources are used for packaging, and the supply chain becomes more complicated with the introduction of 3PL providers, who at times are unable to perform in the market. When a company has to make several of these adaptations over many shipments, the cost eventually will add up. This is especially true when one considers the nature of the industries, such as FMCG, where margins are relatively thin, and scale is required for these firms to become profitable. It will be essential for managers to balance the requirements of daily operations by making adaptations to transportation activities to ensure delivery, and finding more efficient ways of getting the goods to market. 


\section{Warehousing challenges}

Warehousing challenges in emerging markets include inaccurate record-keeping, stacking, store hygiene and safety issues (Coulter, Sondhi \& Boxall 2000:102). Of the participants interviewed, only three had a warehouse outside of South Africa. The rest of the participants used a distributor's warehouse or delivered directly to the market. Participants with their own warehouses commonly collaborate with a local partner to access local knowledge and often are forced by legislation to employ local labour. Given that local partnership is a crucial part in ensuring that these activities work in these regions, the companies do not have full control of the operations. These companies have identified manual systems and misalignment of stock systems as the predominant challenges in warehousing operations. These issues arise as a result of inventory control systems and activity management in warehouses being highly manual, resulting in information transfer delays. Furthermore, this difference in systems causes a misalignment of stock levels in South Africa and the other African markets. The following quotes illustrate the participants' experiences in warehousing challenges:

'... It's just the systems that are in place are still very manual way of counting stock, processing orders and so forth. Still very pen and paper-based ...' (P002, male, Depot Manager)

'I think the most common challenge is the misalignment between how we handle our stock ... just how we handle stock, is it on a system or a pen and paper base?' (P002, male, Depot Manager)

Partnering with a distributor presents its own set of challenges, which include managing the service levels, cost levels and compliance with distributor facilities. One participant stated that because of lacking infrastructure and sometimes older buildings, safety standards are compromised and then investment is required in these facilities to get them up to compliance standard. The labour issues are also a source of concern at times, given the variability in terms of labour laws across countries, which then require the appointment of a local labour law expert to ensure compliance:

'So you need to be familiar with those rules and regulations specific to that country. Labour law in Tanzania, Uganda might be completely different to those in Kenya. You can't apply the same law everywhere.' (P004, male, Head of Business Development and Account Manager for Africa)

The findings on manual systems used in warehouses are consistent with previous studies (Coulter et al. 2000:102). For warehousing in these markets, the preferred method is to make use of a distributor which then grants access to physical facilities. From the companies' part of the sample, none are willing to take on the financial burden and the resulting risk of establishing wholly owned facilities.

\section{Warehousing adaptations}

In addressing the challenges of manual and misaligned systems, participants implemented warehouse management systems (WMS) in the different markets in order to standardise the activities and to ensure visibility of processes and stock throughout the different markets.

Two participants have opted for a cross-dock facility used for assortment and distributions to various customers. The following quotes illustrate the participants' perceptions:

'... We implemented SAP about four years ago, again that addressed a lot of processing issues and brought a positive difference in our system.' (P011, male, Operations Executive)

'So we have what we call these cross-dock facilities, in most countries, the product goes there to check, confirm against what each of the documentation is, any shortages, any overs ...' (P010, male, Import and Export Manager)

Managing the distributor, however, is more critical in this case. As discussed above, collaboration with a local partner is essential in order to gain access to market knowledge and infrastructure. Maintaining control over the distributor and having visibility in the storage and movement of the freight is what is critical for the focal firm. The following quote illustrates how this model can be structured:

'So they'll [manufacturers] still sell the product to the distributor, but the distributor will then negotiate KPIs [Key Performance Indicators] and commercials with the manufacturer and the distributor has to have feedback from the supplier to say who he sold it, and for what margin and a whole bunch of other information. So bringing in the whole feedback loop now so that all manufacturers know exactly where their products are going, who they are going to and how much they are being sold for.' (P003, male, Key Accounts Manager)

Identification, selection and partnering with these distributors can allow a company to get an initial foothold in many of these markets.

\section{Order processing challenges}

The context of order processing becomes essential, especially given the complexity and involvement of distributors and local retailers. In most cases, the suppliers are not connected to the ordering systems of the clients or the distributors. The customers or sellers of products are then involved in playing a coordinating role to ensure that manual orders are captured and these details get communicated to the distributors. Participants identified two main challenges associated with order processing: the manual processing of ordering and the lack of support for the management systems implemented in these markets.

The manual systems that continue to be implemented in some markets do not create opportunities for efficient order processing as there is a lack of stock visibility and order replenishment is not generated automatically. The processes of orders are lengthy and inefficient. One of the participants pointed out that most of the support for systems implementation and execution of effective distribution is in South Africa, thus making it difficult to respond promptly to system failures because of geographic distance. It was also costly to transfer support personnel from South Africa. 
The following quotes illustrate the participants' experiences of order processing:

'So the systems I think are a lot more manual than South Africa ... So they would send an order via email, it would not be automatically generated [by the] system between us and them.' (P008, female, Senior Brand Manager)

'Our biggest issue is support. Here [South Africa] it's easier to get people, we've got head office sitting here, we've got people in Durban and regional areas.' (P005, female, Supply Chain IT)

The findings are consistent with the previous studies relating to the general challenges that organisations face with ordering processing, but highlight the introduction of distributors and the coordinating role that is something required by the seller (Croxton 2003:29; Zhang et al. 2010:213). This is further supported by the fact that many of the activities are performed manually. Given that information technology plays an integral role in facilitating efficient logistics operations, the main question now becomes where should companies focus first? Would investment in technology and support aid in more efficient distribution or is it the investment in improved infrastructure for transportation and warehousing which will yield better results?

\section{Order processing adaptations}

To address the challenges, participants are moving towards the implementation of centralised ordering systems, integrating all markets into one system. A centralised system gives customers access to real-time stock information in the distribution centres and it improves the ordering process which can be completed automatically. Getting the distributors to migrate to a centralised system is still a challenge for most companies, but as the sales grow, many companies then buy out the distributor and then have more control over the systems being used:

'In Mozambique, we are almost there. We almost need to decide if we are going on our own or not. Then the questions are do you buy the distributor out or do you wave the capital and start your own business?' (P010, male, Import and Export Manager)

Five of the participating organisations are currently exploring or have implemented centralised systems. The following quote illustrates the perceptions of the participants:

'That's why getting all the stores on the same system for us is critical; the less systems you have interlinked with each other, the less interfaces you have and the less IT personnel needed to be there to maintain all these language differences in the coding, texting and whatever needs to happen. We're currently in the process of getting rid of multiple of our systems, to have one system that links everyone essentially together.' (P001, male, DC Manager)

One participant indicated that they allocate country managers to a specific distributor and in that way 'run the business for the distributor':

'We actually run the business for the distributors in their business and all the ordering and everything is issued to South Africa and South Africa then ships the stocks up to them. So they invoice on their paper, or their invoice is in the country but we actually sell the stock to them because whenever the stock crosses the border the stock needs to be sold to them because you cannot own the stock. You have to sell it to them and then they sell it to the customer.' (P010, male, Import and Export Manager)

Physical ownership also transfers to the distributor and this can create a loss of control for many sellers, given that these products still have to reach end-customers, and the sellers have to implement strict control over the distributors to ensure that their products reach customers within the agreed time frames.

The findings show that close coordination of customer orders and distributors are required and centralised systems are necessary to streamline the order process.

The following sections (i.e. border congestion and informal market) discuss emerging themes from the interviews. Apart from transportation, warehousing and order processing challenges, and adaptions, participants emphasised other physical distribution challenges that they face in emerging African markets.

\section{Border congestion challenges}

Several issues are contributing to border congestions in Africa. Repeated physical inspections of products, strikes, permit delays and poor conditions of borders, amongst other issues, are at the source of the delays, resulting in substantial waiting periods or denied entry (Dadzie 1990:3; Hirschinger et al. 2015:74).

The challenge of unpredictability and stringent regulation is synonymous with regional trade in Africa. The element of unpredictability exists in the inability to determine border processing times. Participants have also reported cases of product rejection because of non-compliance. At the source of this is the constant regulation change. Often, these regulation changes are not effectively communicated to the participants. An element of complexity is added as every country has its own set of regulations. These requirements are often misunderstood or interpreted incorrectly because of the nuanced inconsistencies that exist between the regulations across the markets. Additionally, one participant highlighted unethical practices at borders, such as border officials asking for bribes, to expedite clearance procedures. Failure to respond to this request may result in further delays. The following quotes present the challenges surrounding border regulations:

'Just getting across the border, there is a lot of paperwork and I think those are the two biggest things. So for me, biggest challenges are those two: getting across the border, just, cause it takes time, it really takes time and you can't really plan for how long you are going to stand at the border.' (P005, female, Supply Chain IT)

'You will have stock that's been built, almost ready to go and there's a legislation change on one or two lines that's part of that load, now you have to unpack everything. Sometimes there's legislation changes on the trucks in transit, and they get held up by the border.' (P001, DC Manager) 
The findings of this study confirm the sources of border congestion, as highlighted in the existing literature (Dadzie 1990:3; Hirschinger et al. 2015:74). This goes to show that these organisations not only have to deal with lead time and communication constraints of moving the products from the point of origin, but legislations and duties place a challenge to get the product into a country. Unethical practices are also well known; however, little is performed by local governments to address the issue, which further exacerbates the problem.

\section{Border congestion adaptations}

Border congestions have implications on organisations in varying degrees. Organisations are forced to develop alternative or contingency plans to minimise the impact of delays. Participating organisations use the aid of local representatives with knowledge of the market to keep abreast of regulation changes and ensure regulatory compliance. This has been cited as a key factor in addressing the issue associated with border compliance. Six participants used the aid of local representation to ensure seamless border transition as described in the following quote:

'You see we then relied on our representation in that country and our border because they are the ones that would be dealing or talking regularly with their clearing agent to really should ... how can I say, in tune with ... those local authorities and be getting regular information on any changes.' (P006, female, Export Specialist)

Participants indicated that they had also explored alternative routes with smaller borders in an attempt to avoid congestions. However, rerouting presented its own set of challenges arising from the limited availability of the borders. The small borders were only available on weekdays. However, these alternative routes alleviated some of the issues associated with the main borders. This is presented in the following quotation:

'People use the Ghana port as an alternative to Nigeria because it's just the ease of getting your goods through the port officials.' (P004, male, Head of Business Development and Account Manager for Africa)

\section{Informal market challenges}

Individuals in rural communities in African markets access goods and services through street hawkers, vendors and mom-and-pop shops, which represent a significant percentage of the overall market activity in emerging markets (Dadzie 1990:31; Rivera-Santos et al. 2015:65; Shacklett 2014:31).

Only five participants in this study served the informal market. However, there were inefficiencies that existed in serving this market because of the uneconomical quantities and high cost associated with serving this market. Customers in this market typically ordered smaller quantities more frequently, resulting in high costs. Accessibility to the market is further hindered by the poor infrastructure in rural communities. Challenges faced in serving this market are revealed in the following quotes:

'In realising the characteristics of the informal market which is basically a fragmented market. They buy very little quantities not economic for delivery, they buy multiple times in a day, they operate outside standard normal hours than a setup retailer would do.' (P011, male, Operations Executive)

'The biggest, biggest challenge is the road infrastructure. That is a big, big challenge. That is a potential hindrance for us delivering directly to the smaller, informal market.' (P002, male, Distribution Centre Manager)

Interestingly, one participant stated that even with the help of a local distributor, accessing and serving informal markets are not easily accomplished:

'When you start looking at informal retail, that's one of the things that the distributors don't always get to. So you must sniff out the market, because they won't always deliver, they are not going to deliver from their warehouse to the spaza stores or something. So you get into the bigger retail outlets in Africa but you don't always get into their informal markets.' (P008, female, Senior Band Manager)

The size of the market and the challenges that exist in serving this market are supported in the literature (Dadzie 1990:31; Parmigiani \& Rivera-Santos 2014:65; Shacklett 2014:31). However, serving this market necessitated changes in addressing the contextual challenges that exist in serving this market. Research on the BOP has, to an extent, provided direction on how to serve these consumers; however, given the significant growth in the middle-income markets in African countries, companies will also be faced with the challenges of catering to this segment.

\section{Informal market adaptations}

Existing literature highlights the need to adapt distribution models in order to successfully serve this market (Fawcett \& Waller 2015:234; Wood 2016:4). However, adapting has posed a challenge to multinational organisations. All participants acknowledged the challenges. However, only two participants had invested resources in distribution models to address the complexities that existed in serving this market. One of the participants had to adapt the type of vehicle used for delivery because it was not economical to have large trucks going into the informal markets. Additionally, with the informal market, participants had to adopt frequent deliveries in smaller quantities. This distribution model is presented in the quotation below:

'So basically we put in a little truck that is a cash band, we load stock onto the truck and the driver drives to all the rural shops and then sells off the truck.' (P012, male, General Manager)

'So you find that in those areas we tend to go much more frequently. We accept minimum orders that are much less than our standard and the type of vehicle we tend to use to do those deliveries is also different from the other established retailers or sellers, etc.' (P011, male, Operations Executive)

Other participants served this market with the assistance of other organisations with large distribution footprints in this 
market to drive efficiency. This is presented in the following quotation:

'For us to do that is economically quite expensive. What we need to do is find other customers that are actually going into that region and find economies of scale to get higher loads and more frequency to those regions to reduce the cost.' (P004, male, Head of Business Development and Account Manager for Africa)

Literature has highlighted the unique nature of the distribution models implemented in the informal market (Fawcett \& Waller 2015:235; Parmigiani \& Rivera-Santos 2014:64; Pitta, Guesalaga \& Marshall 2008:400; Prahalad 2012:10) and findings regarding the informal markets highlight the implementation of the nature of these models in this market. Clearly, local collaboration is required, especially when one intends to serve smaller segments in the country. This might be a more affordable alternative as compared to investing in different configurations of vehicles.

\section{Nuances of African markets}

Africa presents a challenge because of the multifaceted and complex nature of this market. Organisations have to navigate through the different regulations, culture and politics in each country which are ultimately the sources of the complexities. Every country is different. These differences exist in regulations, market requirements, ease of doing business and infrastructure. These differences are presented in the following quotes:

'I don't know but it feels like that you know but you know each one, has nothing really stands out for any particular country because they are so unique you know to what they require and it's not like you comparing apples with apples you know each one is individual.' (P006, female, Export Specialist)

'We can measure, doing business in Ghana is a lot easier than doing business in Nigeria. Doing business in Kenya is a lot easier than doing business with Tanzania and Uganda.' (P004, male, Head of Business Development and Account Manager for Africa)

Trade agreements positively contribute to the ease of doing business. Southern African Development Community (SADC) has contributed to the ease of doing business in Southern Africa. Thus, managing physical distribution within a member country is less complicated compared to non-member countries. Furthermore, one of the participants highlighted that Southern African countries generally have similar market requirements; this provides the organisation with the leverage to standardise several aspects across markets, alleviating the challenges associated with adjusting to each market. Southern Africa presents the least amount of challenges for participants. This is presented in the following quotation:

'So in Southern Africa, what is unique is the infrastructure, there is excellent infrastructure, South Africa, Namibia, Botswana, Zambia, and Mozambique. All of those countries trade in a very similar way to one another. So we treat all of those countries as we treat the South African stores.' (P010, male, Export and Import Manager)
East, West and North Africa present a high degree of complexity. The people, culture, languages and regulations are vastly different. The challenges presented in these markets require organisations to treat these markets differently from the implementation of unique adaptations to address the contextual challenges:

'The challenges are, for instance in Kenya/Tanzania, we started to do key distribution from the plantation. Now we don't do that anywhere else in Africa, so that's a solution all on its own that we had to figure out there. Nothing we can replicate or do here in SA [South Africa] can be done there.' (P003, male, Key Accounts Manager)

Furthermore, each country may present its own set of unique challenges not present in other markets. Participants have highlighted more heightened concerns with traffic congestion in Kenya than in the other markets. The challenges of vehicle theft have only been reported for Ghana and Nigeria. Some challenges only exist for certain markets or are more exaggerated in others. Literature highlights the nuanced differences that exist across emerging markets in Africa adding to the complexity of operating in this market (Flynn et al. 2015:4; Vögel 2014). The findings of this study confirm the existence of the nuanced difference across the markets.

\section{Discussion}

\section{Managerial recommendations}

It is valuable for multinational organisations to understand that a distinctive difference exists across regions in Africa. Southern Africa presents characteristics that make the trade within these regions easier than North, West or East Africa. There are trade agreements that make the entry and exit more accessible, which alleviates some of the border delays and regulatory compliance issues prevalent in other regions.

The complexity begins as organisations distribute beyond the Southern region as the culture, language and regulation are vastly different. Success in these markets requires a good understanding of culture, the use of a distributor with rich local knowledge, which participants have attributed to the success in these markets. Similarly, local partnerships assist in easing trade in these markets. These partners should be knowledgeable of the market and have the necessary network to get the business off the ground. Strict control is required between sellers and distributors. The use of local representation to stay abreast of regulatory requirements and changes to avoid issues associated with non-compliance also needs attention.

\section{Limitations and directions for future research}

The findings reflected the perspective of participants operating mainly from South Africa. For future research, it is recommended that participants should be based in the African market under investigation for richer and in-depth information. Additionally, the sample size of the study was small in order to get extensive information regarding the physical distribution challenges that multinational 
organisations face across various African markets. For future research, it is recommended that a larger sample size, as well as time and resources, should be considered in order to fully explore the physical distribution challenges that multinational companies face.

\section{Conclusion}

\section{Summary of findings and theoretical implications}

This study sought to gather information on the prevalent physical distribution challenges that multinational organisations are exposed to in emerging markets in Africa more specifically on transportation, warehousing and order processing. Secondly, the study aimed to understand how multinational organisations adjust their distribution activities in response to these challenges.

The physical distribution challenges identified typically reflect the perspectives of organisations primarily based within South Africa or represent the South African branch of a multinational company, which operate within other African markets with the aid of a distributor. A number of transportation challenges were identified that mirrored those in the existing literature, which include weak infrastructure, traffic congestions and long lead times (Dadzie et al. 2015:138; Hirschinger et al. 2015:74; Shacklett 2014:30). Participants also shed light on other challenges concerning vehicle and in-transit product theft and transport cost fluctuations, issues mentioned in the literature to a lesser extent (Castell 2016:32; Mérel et al. 2009:462). Misalignment of stock systems and manual systems are amongst the warehousing challenges explored in the findings, which is supported by the findings of Coulter et al., (2000:102). The difficulty of managing a local distributor has also been highlighted (Games 2012:101), which shares anecdotal evidence for these types of partnerships. Order processing presented a similar set of challenges with manual systems, resulting in the lack of realtime stock visibility. Additionally, participants have reported shortages of support management systems arising from the high cost associated with transferring personnel from South Africa to the respective countries, aspects highlighted as key success factors that should be actively managed (Vögel 2014:702). The coordinating role that a seller has to play in many cases also reveals the complexities of distribution in these markets, which is supported by Croxton (2003:29) and Zhang et al. (2010:213). Literature also highlights the challenges associated with border congestion and informal markets linked with doing business in Africa (Dadzie 1990:3; World Bank 2016:39). The sources of these congestions were tied to regulatory compliance. Border regulation is stringent and constantly changing. These changes are often not communicated effectively, resulting in substantial delays because of non-compliance. An element of complexity is added as each country has its own set of regulations that need to be adhered to. The vast sets of regulations left room for misunderstanding or misinterpretations (Hirschinger et al. 2015:74). Operating in the informal market presents challenges because of the poor infrastructure inefficiencies and high costs associated with serving this segment of the market. Distributors are also not always capable of serving the informal market. Customers typically purchased uneconomical quantities, resulting in higher costs. Poor infrastructure in these rural communities also made it challenging to manoeuvre this market (Fawcett \& Waller 2015; Parmigiani \& Rivera-Santos 2014). The findings also add to the academic knowledge by highlighting the challenges organisations face when serving emerging African markets.

The second research question aimed to gain an understanding of how multinational organisations are adapting their distribution activities to suit the prevalent challenges. For transportation challenges, participants would use more protective packaging, than normal, to alleviate in-transit product damages because of precarious road conditions. In addition to holding additional stock, participants had also explored route planning to bypass the extreme traffic congestion that is found in these markets (Fawcett \& Waller 2015:234; Wood 2016:4). These findings serve to shed light on what previous studies have explored and provided additional details relating to the African markets. For warehousing and order processing challenges, organisations have implemented WMS to standardise activities across the markets. Making use of a local partner and their related facilities is another common way to ensure adequate capacity (Coulter et al. 2000:102). These organisations also outsourced warehousing or used cross-dock facilities for break-bulk activities to alleviate some of the challenges associated with managing and running a warehouse, however, at the expense of some loss of control (Steven \& Britto 2016:55; Wang, Li and Chang 2016:69). In addressing concerns of systems, organisations are utilising the implementation of centralised systems in the different markets (Wang et al. 2016:84). Acquiring a local distributor is another method to regain control and then standardise systems across markets. To address border congestion challenges, participants used local representatives to stay abreast of regulatory compliance procedures to ensure seamless exportation, which was explored by Zhou et al. (2016:1). Participants had also explored the use of alternative routes and borders to bypass excessive congestion found in certain borders. The findings of this study are able to shed light on the sources of border congestions and contingency measures to address the challenges, thus adding to the existing academic knowledge. Ultimately, to face the informal market, participants addressed the inefficiencies by accepting smaller orders, often in the form of cash and using small trucks to deliver to these markets. Existing literature mainly highlights that organisations have to adjust distribution models for the informal market.

Differences exist across markets in Africa. The culture, language and regulations are vastly different. Southern Africa presents an easier environment for business because of the trade agreements and commonalities that exist within Southern African markets (Vögel 2014:704). Based on the participants' views, East, North and West Africa present a 
greater degree of complexity as the markets are vastly different. There are certain challenges that are consistent across the markets. However, certain markets may present their own set of challenges that organisations need to be aware of. The findings of this study contribute to the existing academic knowledge by adding insights into the differences in these markets and highlighting the importance of understanding each African market.

\section{Acknowledgements}

The authors would like to thank Mr Theuns Kotzé, Lecturer: Department of Business Managent, Unitversity of Pretoria, for administrating the research process and assisting with core aspects of the project, such as facilitating the ethical clearance application and providing sound methodological advice.

\section{Competing interests}

The authors have declared that no competing interests exist.

\section{Authors' contributions}

All authors contributed equally to this work.

\section{Funding information}

This research received no specific grant from any funding agency in the public, commercial or not-for-profit sectors.

\section{Data availability statement}

The data that support the findings of this study are available on request from the corresponding author (K.M.). The data are not publicly available because of their containing information that could compromise the privacy of research participants.

\section{Disclaimer}

The views and opinions expressed in this article are those of the authors and do not necessarily reflect the official policy or position of any affiliated agency of the authors.

\section{References}

Agyenim-Boateng, Y. \& Russo, B., 2015, Winning in Africa's consumer market, viewed 11 March 2018, from https://www.mckinsey.com/ /media/McKinsey/Industries/ Consumer $\% 20$ Packaged $\% 20$ Goods/Our\%20Insights/Winning $\% 20$ in $\% 20$ Africas $\% 20$ consumer\%20market/Winning_in_Africas_consumer_market_July.ashx.

Amoako-Gyampah, K. \& Boye, S.S., 2001, 'Operations strategy in an emerging economy: The case of the Ghanaian manufacturing industry', Journal of Operation Management 19(1), 59-79. https://doi.org/10.1016/S0272-6963(00)00046-2

Berman, L.R. \& Blade, S., 2013, Business opportunites and challenges in Africa, viewed 09 March 2018, from https://pdfs.semanticscholar.org/962c/8b70909ec8044e8c 8f01802fa10839d49607.pdf.

Bowersox, D.J., 1969, 'Physical distribution development, current status, and potential', The Journal of Marketing 33(1), 63-70. https://doi.org/10.1177/ 002224296903300111

Braun, V. \& Clarke, V., 2012, 'Thematic analysis', in H. Cooper, P.M. Camic, D.L. Long, A.T. Panter, D. Rindskopf \& K.J. Sher (eds.), APA handbooks in psychology ${ }^{\circledast}$. APA handbook of research methods in psychology, Research designs: Quantitative, qualitative, neuropsychological, and biological, vol. 2. pp. 57-71, American Psychological Association, Washington, D.C., United States. https://doi.org/10.1037/13620-004

Braun, V. \& Clarke, V., 2014, 'Thematic analysis', Qualitative Research in Clinical and Health Psychology 24, 95-114. https://doi.org/10.1007/978-1-137-29105-9_7
Carter, C.R., Rogers, D.S. \& Choi, T.Y., 2015, 'Toward the theory of the supply chain' Journal of Supply Chain Management 51(2), 89-97. https://doi.org/10.1111/ jscm.12073

Castell, H., 2016, 'Transport: Overcoming logistical challenges', Spore 181, 32-33.

Chan, F.T.S., Kumar, N. \& Choy, K.L., 2007, 'Decision-making approach for the distribution centre location problem in a supply chain network using the fuzzybased hierarchical concept', Proceedings of the Institution of Mechanical Engineers, Part B: Journal of Engineering Manufacture 221(4), 725-739. https:// doi.org/10.1243/09544054JEM526

Chikweche, T. \& Fletcher, R., 2012, 'Revisiting the marketing mix at the bottom of pyramid (BOP): From theoretical considerations to practical realities', Journal of Consumer Marketing 29(7), 507-520. https://doi.org/10.1108/0736376121127 5018

Christopher, M., 2016, Logistics \& supply chain management, Pearson, Dorchester.

Ciuci, 2011, Winning in Africa: An investor's guide, viewed 10 August 2018, from https://www.ciuci.us/wp-content/uploads/2011/11/Winning In Africa-Anhttps://www.ciuci.us/wp-conten
investors-guide-toFMCG-vF.pdf.

Coulter, J., Sondhi, J. \& Boxall, R., 2000, 'The economics of grain warehousing in subSaharan Africa', African Review of Money Finance and Banking 97-116, viewed 15 April 2018, from http://www.jstor.org/stable/pdf/23026284.pdf?refreqid=excelsi or\%3A71a0192eaa9b4790f566d1902b31da25.

Craighead, C.W., Ketchen, D.J., Jenkins, M.T. \& Holcomb, M.C., 2017, 'A supply chain perspective on strategic foothold moves in emerging markets', Journal of Supply Chain Management 53(4), 3-12. https://doi.org/10.1111/jscm.12142

Creswell, J.W., 2012, Educational research: Planning, conducting, and evaluating quantitative and qualitative research, 4 th edn., Pearson, Boston, MA.

Croxton, K.L., 2003, 'The order fulfillment process', International Journal of Logistics Management 14(1), 19-32. https://doi.org/10.1108/09574090310806512

Dadzie, K.Q., 1990, 'Transfer of logistics knowledge to third world countries', International Journal of Physical Distribution \& Logistics Management 20(9), 10-16. https://doi.org/10.1108/EUM0000000000375

Dadzie, K.Q., Winston, E. \& Hinson, R., 2015, 'Competing with marketing channels and logistics in Africa's booming markets: An investigation of emerging supply chain management practices in Ghana', Journal of Marketing Channels 22(2), 137-152. https://doi.org/10.1080/1046669X.2015.1018079

Darkow, I.L., Weidmann, M. \& Lorentz, H., 2015, 'Adaptation of foreign logistics service providers' resources and capabilities to a new institutional environment', Journal of Supply Chain Management 51(1), 27-51. https://doi.org/10.1111/ jscm.12068

Deloitte, 2017, Global powers of retailing, viewed 10 August 2018, from https:// www2.deloitte.com/za/en/pages/consumer-industrial-products/articles/globalpowers-of-retailing-2017.html.

Eifert, B., Gelb, A. \& Ramachandran, V., 2008, 'The cost of doing business in Africa: Evidence from enterprise survey data', World Development 36(9), 1531-1546. https://doi.org/10.1016/j.worlddev.2007.09.007

Esper, T.L., Fugate, B.S. \& Davis-Sramek, B., 2007, 'Logistics learning capability: Sustaining the competitive advantage gained through logistics leverage', Journal of Business Logistics 28(2), 57-82. https://doi.org/10.1002/j.2158-1592.2007.tb00058.x

Espino-Rodríguez, T. \& Rodríguez-Díaz, M., 2014, 'Determining the core activities in the order fulfillment process: An empirical application', Business Process Management Journal 20(1), 2-24. https://doi.org/10.1108/BPMJ-01-2013-0012

Fawcett, S.E. \& Waller, M.A., 2015, 'Designing the supply chain for success at the bottom of the pyramid', Journal of Business Logistics 36(3), 233-239. https://doi. org/10.1111/jbl.12096

Flynn, B., Huang, X. \& Zhao, X., 2015, 'Supply chain management in emerging markets: Critical research issues', Journal of Supply Chain Management 51(1), 3-5. https:// doi.org/10.1111/jscm.12069

Games, D., 2012, Business in Africa-corporate insights, Penguin, London.

Gu, J., Goetschalckx, M. \& McGinnis, L.F., 2010, 'Research on warehouse design and performance evaluation: A comprehensive review', European Journal of Operational Research 203(3), 539-549. https://doi.org/10.1016/j.ejor.2009.07.031

Guest, G., Bunce, A. \& Johnson, L., 2006, 'How many interviews are enough? An experiment with data saturation and variability', Field Methods 18(1), 59-82. experiment with data saturation and variab
https://doi.org/10.1177/1525822X05279903

Hauk, J.G., 1964, 'Logistics and physical distribution management in the military', Transportation Journal 4(2), 12-19.

Havenga, J., Simpson, Z., King, D.D., De Bod, A. \& Braun, M., 2016, Logistics barometer South Africa 2016, viewed 08 October 2018, from https://www.sun.ac.za/english/ faculty/economy/logistics/Documents/Logistics\%20Barometer/Logistics $\% 20$ Barometer\%202016\%20Report.pdf.

Hirschinger, M., Spickermann, A., Hartmann, E., Gracht, H. \& Darkow, I.L., 2015 'The future of logistics in emerging markets - Fuzzy clustering scenarios grounded in institutional and factor-market rivalry theory', Journal of Supply Chain Management 51(4), 73-93. https://doi.org/10.1111/jscm.12074

$\mathrm{Hu}, \mathrm{L} ., 2018$, 'The Chinese market as an opportunity to innovate distribution strategies? Evidences from Italian firms', European Business Review 30(5), 607-626. https://doi.org/10.1108/EBR-09-2017-0174

Hugo, A., 2016, Prospects in retail and consumer goods sector in ten sub-Saharan countries, viewed 10 March 2018, from https://www.pwc.co.za/en/assets/pdf/ retail-in-africa.pdf.

Huq, F.A., Chowdhury, I.N. \& Klassen, R.D., 2016, 'Social management capabilities of multinational buying firms and their emerging market suppliers: An exploratory study of the clothing industry', Journal of Operations Management 46, 19-37. https://doi.org/10.1016/j.jom.2016.07.005 
Iyer, A., Lee, H.L. \& Roth, A., 2013, 'Introduction to special issue on POM research on emerging markets', Production and Operations Management 22(2), 233-235. https://doi.org/10.1111/poms.12055

Jackson, T., 2011, 'From cultural values to cross-cultural interfaces: Hofstede goes to Africa', Journal of Organizational Change Management 24(4), 532-558. https:// doi.org/10.1108/09534811111144656

Khan, K.A., Bakkappa, B., Metri, B.A. \& Sahay, B., 2009, 'Impact of agile supply chains' delivery practices on firms' performance: Cluster analysis and validation', Supply Chain Management: An International Journal 14(1), 41-48. https://doi.org/10. $1108 / 13598540910927296$

Lambert, V.A. \& Lambert, C.E., 2012, 'Qualitative descriptive research: An acceptable design', Pacific Rim International Journal of Nursing Research 16(4), 255-256.

Larson, P.D., Poist, R.F. \& Halldórsson, Á., 2007, 'Perspectives on logistics vs. SCM: A survey of SCM professionals', Journal of Business Logistics 28(1), 1-24. https://doi. org/10.1002/j.2158-1592.2007.tb00230.x

Lau, H.C. \& Lee, W., 2000, 'On a responsive supply chain information system', International Journal of Physical Distribution \& Logistics Management 30(8), 598-610. https://doi.org/10.1108/09600030010346242

Lee, M.C., 2006, 'The 21st century scramble for Africa', Journal of Contemporary African Studies 24(3), 303-330. https://doi.org/10.1080/02589000600976570

Lietz, C.A. \& Zayas, L.E., 2010, 'Evaluating qualitative research for social work practitioners', Advances in Social Work 11(2), 188-202. https://doi.org/10. 18060/589

Lincoln, Y.S. \& Guba, E.G., 1985, Naturalistic inquiry, Sage, Newbury Park, CA.

Lu, C.-S. \& Yang, C.-C., 2010, 'Logistics service capabilities and firm performance of international distribution center operators', The Service Industries Journal 30(2), 281-298. https://doi.org/10.1080/02642060802123392

Luiz, J.M., 2006, 'The wealth of some and the poverty of sub Saharan Africa', International Journal of Social Economics 33(9), 625-648. https://doi. org/10.1108/03068290610683422

Lysonski, S. \& Durvasula, S., 2013, 'Nigeria in transition: Acculturation to global consumer culture', Journal of Consumer Marketing 30(6), 493-508. https://doi. org/10.1108/JCM-07-2013-0626

Meacham, M., Tymms, A., Moolman, T. \& De Montgolfier, J., 2012, Lessons from Africa's pioneers: How successful consumer goods companies overcome the five great challenges of doing business on the continent, viewed 08 March 2018, from https://www.bain.com/insights/lessons-from-africas-pioneers/.

Mérel, P.R., Sexton, R.J. \& Suzuki, A., 2009, 'Optimal Investment in transportation infrastructure when middlemen have market power: A developing-country analysis', American Journal of Agricultural Economics 91(2), 462-476. https://doi. org/10.1111/j.1467-8276.2008.01245.x

Mesquita, L.F., Lazzarini, S.G. \& Cronin, P., 2007, 'Determinants of firm competitiveness in Latin American emerging economies: Evidence from Brazil's auto-parts industry', International Journal of Operations \& Production Management 27(5), 501-523. https://doi.org/10.1108/01443570710742384

Mueller, G. \& Mueller, A., 2007, 'Warehouse demand and the path of goods movement', Journal of Real Estate Portfolio Management 13(1), 45-56.

Neergaard, M.A., Olesen, F., Andersen, R.S. \& Sondergaard, J., 2009, 'Qualitative description-the poor cousin of health research?', BMC Medical Research Methodology 9(1), 52-56. https://doi.org/10.1186/1471-2288-9-52

Nnamdi, O. \& Owusu, R., 2014, 'Africa as a source location: Literature review and implications', International Journal of Emerging Markets 9(3), 424-438. https:// doi.org/10.1108/IJoEM-09-2012-0123

Ouma, S., 2012, 'The new scramble for Africa', Regional Studies 46(6), 836-838. https://doi.org/10.1080/00343404.2012.691237

Parmigiani, A. \& Rivera-Santos, M., 2014, 'Sourcing for the base of the pyramid: Constructing supply chains to address voids in subsistence markets', Journal of Operations Management 33, 60-70. https://doi.org/10.1016/j.jom.2014. 10.007

Pedersen, P., 2003, 'Development of freight transport and logistics in sub-Saharan Africa: Taaffe, Morrill and Gould revisited', Transport Reviews 23(3), 275-297. https://doi.org/10.1080/0144164032000091681

Percy, W.H., Kostere, K. \& Kostere, S., 2015, 'Generic qualitative research in psychology', The Qualitative Report 20(2), 76-85.

Pitta, D.A., Guesalaga, R. \& Marshall, P., 2008, 'The quest for the fortune at the bottom of the pyramid: Potential and challenges', Journal of Consumer Marketing 25(7), 393-401. https://doi.org/10.1108/07363760810915608

Polit, D.F. \& Beck, C.T., 2012, Nursing research: Generating and assessing evidence for nursing practice, 9th edn., Wolters Klumer Health, Lippincott Williams \& Wilkins, Philadelphia, PA.
Prahalad, C.K., 2012, 'Bottom of the pyramid as a source of breakthrough innovations', Journal of Product Innovation Management 29(1), 6-12. https://doi.org/10.1111/ j.1540-5885.2011.00874.x

Ravet, D., 2013, 'Delivering sustainability through supply chain distribution network redesign', Central European Business Review 2(3), 22-29. https://doi.org/10. $18267 /$ j.cebr.51

Rexhausen, D., Pibernik, R. \& Kaiser, G., 2012, 'Customer-facing supply chain practices - The impact of demand and distribution management on supply chain success', Journal of Operations Management 30(4), 269-281. https://doi.org/10.1016/j. jom.2012.02.001

Rivera-Santos, M., Holt, D., Littlewood, D. \& Kolk, A., 2015, 'Social entrepreneurship in sub-Saharan Africa', Academy of Management Perspectives 29(1), 72-91. https:// doi.org/10.5465/amp.2013.0128

Rogers, D.S. \& Leuschner, R., 2004, 'Supply chain management: Retrospective and prospective', Journal of Marketing Theory and Practice 12(4), 60-65. https://doi. org/10.1080/10696679.2004.11658533

Rowley, J., 2012, 'Conducting research interviews', Management Research Review 35(4), 260-271. https://doi.org/10.1108/01409171211210154

Saunders, M.N.K., Lewis, P. \& Thornhill, A., 2016, Research methods for business students, 7th edn., Pearson, Harlow.

Schary, P.B., 1970, 'The dimensions of physical distribution', Transportation Journal 10(1), 5-16.

Schlesinger, J., Cook, M., Rigby, D. \& Chu, J., 2001, 'Order fulfillment delivering the e-promise', Ivey Business Journal 65(6), 14-19.

Shacklett, M., 2014, 'SCM spells success in emerging markets', World Trade, WT 100 27(6), 28-31.

Shang, J., Yildirim, T.P., Tadikamalla, P., Mittal, V. \& Brown, L.H., 2009, 'Distribution network redesign for marketing competitiveness', Journal of Marketing 73(2), 146-163. https://doi.org/10.1509/jmkg.73.2.146

Shenton, A.K., 2004, 'Strategies for ensuring trustworthiness in qualitative research projects', Education for Information 22(2), 63-75. https://doi.org/10.3233/EFIprojects, Ed

Shou, Z., Zheng, X.V. \& Zhu, W., 2016, 'Contract ineffectiveness in emerging markets: An institutional theory perspective', Journal of Operations Management 46, 38-54. https://doi.org/10.1016/j.jom.2016.07.004

Southern, R.N., 2011, 'Historical perspective of the logistics and supply chain management discipline', Transportation Journal 50(1), 53-64. https://doi. org/10.5325/transportationj.50.1.0053

Steven, A.B. \& Britto, R.A., 2016, 'Emerging market presence, inventory, and product recall linkages', Journal of Operations Management 46(1), 55-68. https://doi org/10.1016/j.jom.2016.07.003

Van den Berg, J.P. \& Zijm, W.H., 1999, 'Models for warehouse management: Classification and examples', International Journal of Production Economics 59(1-3), 519-528. https://doi.org/10.1016/S0925-5273(98)00114-5

Villarreal, B., Garcia, D. \& Rosas, I., 2009, 'Eliminating transportation waste in food distribution: A case study', Transportation Journal 48(4), 72-77.

Vögel, A.J., 2014, 'Strategies for serving the base of the pyramid-lessons from subSaharan Africa', Mediterranean Journal of Social Sciences 5(23), 702-710. https:// doi.org/10.5901/mjss.2014.v5n23p702

Wilson, G., 1961, 'What's new in physical distribution', Transportation Journal 1(2), 22-25. https://doi.org/10.2307/1248956

Wang, J.J., Li, J.J. \& Chang, J., 2016, 'Product co-development in an emerging market: The role of buyer-supplier compatibility and institutional environment', Journal of Operations Management 46(1), 69-83. https://doi.org/10.1016/j.jom.2016.07.002

Wood, M., 2016, Africa rising, viewed 10 March 2018, from https://aperio.co.za/ index.php/download-aperio-s-latest-white-paper-africa-rising

World Bank, 2016, Trade logistics in the global economy, viewed 16 March 2018, from https://lpi.worldbank.org/report.

Wu, F., Yeniyurt, S., Kim, D. \& Cavusgil, S.T., 2006, 'The impact of information technology on supply chain capabilities and firm performance: A resource-based view', Industrial Marketing Management 35(4), 493-504. https://doi. org/10.1016/j.indmarman.2005.05.003

Yin, R.K., 2017, Case study research and applications: Design and methods, Sage, Thousand Oaks, CA.

Zhang, L.L., Lee, C.K. \& Xu, Q., 2010, 'Towards product customization: An integrated order fulfillment system', Computers in Industry 61(3), 213-222. https://doi. org/10.1016/j.compind.2009.09.003

Zhou, K.Z., Su, C., Yeung, A. \& Viswanathan, S., 2016, 'Supply chain management in emerging markets', Journal of Operations Management 46(1), 1-4. https://doi. org/10.1016/j.jom.2016.07.007 


\section{Appendix 1}

TABLE 1-A1: The link between the codes, sub-themes and main themes identified in this study.

\section{Raw data extracts}

'But we knew in some of these African countries, it's a lot more difficult to try and predict exactly how long a depot is going to be taking.' (P004, male, Head of Business Development and Account Manager for Africa)

'If you are in the middle of Nairobi, it can take a truck at least two to three hours to get out within a kilometre distance from the warehouse ... There is a congestion in these countries that sometimes, quite incredible, compared to what we experience here [South Africa].' (P004, male, Head of Business Development and Account Manager for Africa)

'... Then for us becomes an issue with the actual product on the truck because of the heat, so especially with our candy and those sort of categories, you can get products that can melt ...' (P008, female, Senior Brand Manager)

'The big thing is theft, utilising our assets outside working hours. It's a common problem we had in Nigeria and Ghana. Vehicles gone missing, fuel going stole.' (P004, male, Head of Business Development and Account Manager for Africa)

'And road transport costs vary considerably, especially with the exchange rate consistently changing. As an example, Mozambique exchange rate fluctuates daily, so those transport costs are changed daily ...' (P008, female, Senior Brand Manager)

'The biggest challenge is the road infrastructure. That is a big challenge. That is a potential hindrance for us delivering directly to the smaller, informal market.' (P002, male, Depot Manager)

'... Where you are going to regions or areas that are not common for your business would typically then engage certain subcontractors who frequent those typical regions.' (P004, male, Head of Business Development and Account Manager for Africa)

'We don't have any DCs close by, so they need to be able to plan for maybe 21 days, 30 days or 90 days.' (P005, female, Supply Chain IT)

'... We will put a thicker layer of shrink wrap purely because of the poor roads that these trucks have to travel on ...' (P002, male, Depot Manager)

'So what can also happen is you can look at rerouting via different borders so going through ... you know for Zambia we experimented a little bit to try different route to say instead of going through Kazungula lets go to Livingstone.' (P006, female, Export Specialist)

'I think the most common challenge is the misalignment between how we handle our stock ... just how we handle stock, is it on a system or a pen and paper base?' (P002, male, Depot Manager)

... It's just the systems that are in place are still very manual way of counting stock, processing orders and so forth. Still very pen and paper-based...' (P002, male,

Depot Manager)

'... We implemented SAP about four years ago, again that addressed a lot of processing issues brought positive difference in our system.' (P011, male,

Operations Executive)

'So we have what we call these de-stuff facilities, in most countries, the product goes there to check, confirm against what each of the documentation is, any shortages, any overs ...' (P010, male, Import and Export Manager)

'So the systems I think are a lot more manual than South Africa ... So it will be on the email, it will be not be automatically generated [by the] system between us and them.' (P008, female, Senior Brand Manager)

'So I think that's the biggest thing, the unpredictability of some of these markets in terms of being able to plan in time in specific time frames.' (P004, male, Head of Business Development and Account Manager for Africa)

'You will have stock that's been built, almost ready to go and there's a legislation change on one or two lines that's part of that load; now you have to unpack everything, remove the item from the bills lading, do a brand-new bill ladin application and carry on. So there's sometimes that complexity that delays bein able to distribute. Sometimes there's legislation changes on the trucks in transit and they get held up by the border.' (P001, DC Manager)

'There is a lot of volatility in running and managing a business within Africa. So it's borders, its changing infrastructures and changing of legislations, thos are the biggest challenges.' (P010, male, Import and Export Manager)

'Sometimes these decisions are made and implemented and not always communicated, so you know then you incur the mirage because the vehicles will communicated, so you know then you incur the
just get stuck.' (P006, female, Export Specialist)

'We work on 6 days for Zimbabwe because sometimes they have a like a [inaudible] inspection that takes place so they might randomly say ok this truck you know we going to inspect.' (P006, female, Export Specialist)

'So the first, probably the biggest challenge that one has exporting into Africa is the complexity and variability of pre-export compliance checks and every country, I'm sure you've done your research, has their own unique

compliances.' (P010, Male Import and Export Manager)

We might see a particular product appear on a particular tariff and then another country would say that they don't see it under that tariff so they would be [inaudible] between the two markets and you know that can then cause your [transport] assignment to be rejected.' (P010, Male Import and Export Manager) 'Port congestion in Nigeria is hectic.' (P004, male, Head of Business Development and Account Manager for Africa)

\section{Codes}

Long lead time

Sub-themes

Transportation challenges

Main themes

Traffic congestion

Transportation challenges

In-transit product damage

Transportation challenges

Security

Transportation challenges

Transport cost

Transportation challenges

Weak infrastructure

Transportation challenges

Outsourcing: 3PL

Transportation adaptations

Adaptations

Safety stock

Transportation adaptations

Misaligned stock systems

Transportation challenges

Challenges

Manual systems

Transportation challenges

Warehouse management system WMS

Warehousing adaptations

Adaptations

Cross-dock facilities

Warehousing adaptations

Manual systems

Order processing challenges

Challenges

Lack of system support

Order processing challenges

Centralised system

Order processing adaptations

High degree of unpredictability

Border congestion challenges

Constant regulation change

Border congestion challenges Challenges

Border congestion challenges Challenges

Random inspections

Border congestion challenges Challenges

Different regulation across countries Border congestion challenges Challenges

Interpretation of regulation

Border congestion challenges Challenges

Border congestion

Border congestion challenges Challenges 
TABLE 1-A1 (Continues...): The link between the codes, sub-themes and main themes identified in this study.

\section{Raw data extracts}

'And then you get into a point where, unforeseen stuff happens, maybe they are not going to allow to go through the border because there was one thing on checklist that wasn't completed or say they are striking.' (P005, female, Supply Chain IT)

'We are not a company that participates in under the table dealings, so you get border congestion, you're last in queue, they help the guys behind you because they're willing to slip a buck or two.' (P001, male, DC Manager)

'You see we then relied on our representation in that country and our border because they are the ones that would be dealing or talking regularly with their clearing agent to really should ... how can I say, in tune with ... those local authorities and be getting regular information on any changes.' (P006, female, Export Specialist)

'People use the Ghana port as an alternative to Nigeria because it's just the ease of getting your goods through the port officials.' (P004, male, Head of Business Development and Account Manager for Africa)

'The mitigated strategies that one can do is firstly the safety stock and the second would be ship earlier than one would expect to ship.' (P001, male, DC Manager)

'In realising the characteristics of the informal market which is basically a fragmented market.' They buy very little quantities not economic for delivery, they buy multiple times in a day, they operate outside standard normal hours that a setup retailer would do.' (P011, male, Operations Executive)

'The biggest, biggest challenge is the road infrastructure. That is a big, big challenge. That is a potential hindrance for us delivering directly to the smaller, informal market.' (P002, male, Distribution Centre Manager)

'So basically we put in a little truck that is a cash band, we load stock onto the truck and the driver drives to all the rural shops and then sells off the truck.' (P012, male, General Manager)

'So you find that in those areas we tend to go much more frequently. We accept minimum orders that are much less than our standard and the type of vehicle we tend to use to do those deliveries is also different from the other established retailers or sellers, etc.' (P011, male, Operations executive)

'For us to do that is economically quite expensive. What we need to do is find other customers that are actually going into that region and find economies of scale to get higher loads and more frequency to those regions to reduce the cost.' (P004, male, Head of Business Development and Account Manager for Africa)

\section{Codes}

Strikes

Sub-themes

Main themes

Border congestion challenges Challenges

Bribes

Border congestion challenges Challenges

Local representation

Border congestion

Adaptations

adaptations

Rerouting

Border congestion adaptations

Adaptations

Safety stock

Border congestion adaptations

Adaptations

Uneconomical order quantities

Informal market challenges

Challenges

Poor infrastructure

Informal market challenges Challenges

Small truck

Informal market adjustment Adjustment

Minimum order quantiles

Informal market adjustment Adjustment

Collaborative distribution mode

Informal market adjustment Adjustmen 